\title{
Margaret McCartney: The false god of appraisal
}

\author{
Margaret McCartney general practitioner, Glasgow
}

Twenty three minutes on a train. Until a couple of years ago I used the time spent on this regular journey thinking about things I'd like to write about, or the best birthday presents for friends, the colour of the trees rushing by, the enticing smell of other people's fish and chips. That time was mine. It was aimless but gloriously, fruitfully productive.

This has stopped. Appraisal now means that I use those 23 minutes writing down my "learning activities" from the week before. Appraisal means that I must keep collecting evidence of professional development. It is a sacrifice to the god of revalidation-because only when written down is something proved to have happened.

Like everyone else, I look up things I don't know about during the course of the day-diagnoses I'm unsure of, drug interactions I've forgotten, treatments that are new to me. But I don't write it down as I go because, despite coming to work earlier and leaving later, minutes spent on myself mean fewer spent on patients.

Appraisal is a false god. It is a waste of time and a misuse of resources. It was never going to "stop another Shipman." Of course, it's nice to have a conversation with a fellow GP about the work we do and the hazards we face-but if it takes appraisal for this to happen once a year, it's the working conditions that are the problem, and appraisal is not the solution.

What are your strengths and weaknesses? What are your reflections on learning? What have you learnt from this activity? What changes have you made? The questions invite answers by rote from a numb mind.

Appraisal now includes "360 degree feedback," which means that each of the United Kingdom's 43000 GPs sends an appraisal every five years to 15 peer raters. If the 10 minutes it takes me to fill one in is the average, then health professionals spend 21500 hours a year ticking boxes rating colleagues. Where is the evidence of value? What work-or what life enhancing, burnout reducing, play away from work-is not getting done instead? Look to business: the financial services company Accenture has just got rid of annual appraisals for employees. ${ }^{1}$ Bravo!

What of the harms? I know of several doctors who have had vile slurs written on feedback documents. How many others have retired early because of stress brought on by appraisal? Complaints against doctors are rising, not falling ${ }^{2}$ - any hopes that the process would help are unfounded.

Yet our colleges have signed up to this time wasting, navel gazing, and expensive process without properly considering either the opportunity costs or whether the endeavour is evidence based.

Competing interests: I have read and understood the BMJ policy on declaration of interests and declare the following interests: I'm an NHS GP partner, with income partly dependent on Quality and Outcomes Framework points. I've written two books and earn from broadcast and written freelance journalism. I'm an unpaid patron of Healthwatch. I make a monthly donation to Keep Our NHS Public. I'm a member of Medact. I'm occasionally paid for time, travel, and accommodation to give talks or have locum fees paid to allow me to give talks but never for any drug or public relations company. I was elected to the national council of the Royal College of General Practitioners in 2013 and am chair of its standing group on overdiagnosis. I have invested a small amount of money in a social enterprise, Who Made Your Pants?

Provenance and peer review: Commissioned; not externally peer reviewed.

Follow Margaret on Twitter, @mgtmccartney

1 Vara V. The push against performance reviews. New Yorker2015 Jul 24. www.newyorker com/business/currency/the-push-against-performance-reviews.

2 Archer J, Regan de Bere S, Bryce M, et al; Plymouth University Peninsula Schools of Medicine and Dentistry. Understanding the rise in fitness to practice complaints from members of the public. 30 Jan 2014. www.gmc-uk.org/static/documents/content/Archer_ et_al_FTP_Final_Report_30_01_2014.pdf.

Cite this as: BMJ 2015;351:h4982

๑ B BMJ Publishing Group Ltd 2015 